\title{
EFFECTS OF A HEXOESTROL DERIVATIVE, ERYTHRO-MEA, ON EARLY PREGNANCY IN THE MOUSE
}

\author{
K. W. HUMPHREY AND G. W. EMMENS \\ Department of Veterinary Physiology, University of Sydney, N.S.W., Australia
}

(Received 5th September 1968)

\begin{abstract}
Summary. The effects of erythro-MEA (erythro-ethyl- $\alpha^{\prime}$-methyl-4,4'dihydroxybibenzyl) on tubal transport and implantation in the mouse were studied. When given on Days 1 to 3 of pregnancy, erythro-MEA causes tube-locking of some ova, reduces the recovery of ova to $60 \%$ of that in controls, and has similar effects to oestradiol. Treatment with this compound inhibits the deciduoma reaction and implantation of transferred ova in pseudopregnant and progesterone-treated, ovariectomized mice. When given to mice with delayed blastocysts, erythro-MEA induces implantation in $50 \%$ of mice and prevents oestradiol-induced implantation in others. In this system, erythro-MEA has both oestrogenic and antioestrogenic properties, but it is concluded that its anti-fertility actions may, in part, be due to its anti-oestrogenic property.
\end{abstract}

\section{INTRODUCTION}

Implantation and pregnancy in some laboratory animals require a balance between progesterone and oestrogen (Courrier, 1950; Humphrey, 1967a, b). Anti-oestrogenic compounds have been used as antifertility agents in the belief that their effectiveness is due to antagonism of endogenous oestrogens (see Duncan \& Forbes, 1965; Emmens, 1965, 1967; Schlough \& Meyer, 1965).

Unfortunately, many of these anti-oestrogenic compounds exhibit other hormonal properties, including oestrogenic, progestational and anti-gonadotrophic actions (Pincus, Chang, Zarrow, Hafez \& Merrill, 1956; Emmens, 1965, 1967; Emmens \& Martin, 1965) and it is difficult to be certain of the modes of action of these substances when preventing implantation in the intact animal.

Recent work in this laboratory has shown that normal pregnancies can be established in hormone-treated, ovariectomized mice, rats and rabbits by the ovum transfer technique (Humphrey, 1967a, 1968a, 1969). In progesteronetreated, ovariectomized mice, implantation is oestrogen-dependent, while oestrogen before transfer does not render the uterus refractory to a second, inducing dose of oestradiol (Humphrey, 1969). Similarly, implantation of delayed blastocysts in ovariectomized pregnant mice is oestrogen-dependent, 
although the dose of oestrogen is not a critical parameter (Humphrey, 1967c).

It is possible to study the effects of various compounds on oestradiol-induced implantation in ovariectomized mice and thus eliminate the possibility that the substances act as anti-gonadotrophins. Dimethylstilboestrol (DMS) and the 19-nortestosterone derivative, U-10997 (7-17-dimethyl-19-nortestosterone) induce implantation of delayed blastocysts and appear to act as oestrogens. By contrast, the impeded oestrogens U-11100A (1-[2-( $p$-[3,4-dihydro-6-methoxy-2phenyl-1-naphthyl]phenoxy)ethyl]-pyrrolidine hydrochloride) (Emmens \& Martin, 1965), and oestriol and MRL-37 (1-[p-2-diethylaminoethoxyphenyl]-1phenyl-anisylethane), MER-25 (1-[ $p$-2-diethylaminoethoxyphenyl)-1-phenyl2-anisylethane) and U-1555A (2-[ $p$-(6-methoxy-2 phenylinden-3-yl)-phenoxy]triethylamine) inhibit oestradiol-induced implantation in some mice and appear to act as anti-oestrogens (Humphrey, 1967b, c, 1968b).

Emmens (1967) has surveyed the antifertility and hormonal properties of the hexoestrol derivative erythro-MEA (erythro- $\alpha$-ethyl- $\alpha^{\prime}$-methyl-4,4'-dihydroxybibenzyl), and concluded that this substance probably prevents pregnancy in the mouse by anti-oestrogenic pathways.

This paper describes experiments investigating the effects of erythro-MEA on tubal transport and decidualization in the mouse and on oestradiol-induced implantation in ovariectomized mice.

\section{MATERIALS AND METHODS}

Randomly bred mice of the QS strain were used in all experiments. Pregnant and pseudopregnant females were obtained by mating with fertile and vasectomized males, respectively. In all but one experiment, mating was induced by treatment with gonadotrophins (Humphrey, 1968b). The day of finding the vaginal plug was termed Day 1 of the experiment.

Virgin mice were ovariectomized and 7 to 21 days later received $0.1 \mu \mathrm{g}$ of oestradiol-17 $\beta$ for 3 days followed by $1 \mathrm{mg} /$ day of progesterone, usually for 8 days. The first day of progesterone treatment was termed Day 1.

\section{Experiments}

1. Studies of ovum transport and implantation. Pregnant mice received varying doses of erythro-MEA or the vehicle only on Days 1 to 3 , and were killed either on Day 4, when the tract was flushed for ova (Humphrey \& Martin, 1968a, b) or on Day 12 when the uterus was examined for implantations.

2. Studies of the deciduoma reaction. Deciduomata were induced by intraluminal injection of $10 \mu \mathrm{l}$ of peanut oil at 18.00 hours on Day 4 of pseudopregnancy or at 16.00 hours on Day 5 of progesterone treatment. The mice were killed $96 \mathrm{hr}$ after stimulation and the deciduomata scored (DIS of 0 to 4 , based on the proportion of the treated horn that decidualizes) and weighed (Humphrey, 1968c). The ovariectomized mice received $0.025 \mu \mathrm{g}$ of oestradiol at 10.00 hours on Day 5 to increase uterine sensitivity to the intraluminal oil (Humphrey, 1967a, 1969). Gonadotrophins were not used to induce mating of the intact mice in these experiments since deciduomata are not readily induced in mice so treated.

3. Ovum transfer experiments. Donor mice were superovulated by treatment with 
10 i.u. of PMSG (Primantron, Schering) followed after $54 \mathrm{hr}$ by 10 i.u. of HCG (Pregnyl, Organon), and pairing with fertile males. The pregnant mice were killed on Day 4 and the uteri flushed with Hanks' solution, containing $1 \mathrm{mg} / \mathrm{ml}$ each of glucose and bovine serum albumin. Eight ova were selected at random and transferred to the right uterine horn of pseudopregnant or progesteronetreated, ovariectomized recipients (Humphrey, 1967a, 1968b, 1969). Pseudopregnant host mice received erythro-MEA or the vehicle only on Days 1 to 3 and transfers were performed on Day 4. Ovariectomized mice received erythroMEA or oil on Days 2 to 4 of progesterone, transfers were performed on Day 4 and $1 \mathrm{mg}$ Provera ( $6 \alpha$-methyl-17 $\alpha$-acetoxy-progesterone, Upjohn Co.) was given daily from Days 5 to 11 to maintain the implants (Humphrey, 1969). A single dose of $0.025 \mu \mathrm{g}$ of oestradiol was given on Day 5 or 6 of pseudopregnancy, or on Day 5, 6 or 7 in ovariectomized mice in an attempt to induce implantation (Humphrey, 1967a, 1969). The mice were killed 8 days after transfer and the implants counted.

4. Studies of delayed implantation. General procedures were as described by Humphrey (1967b, c, 1968b). Pregnant mice were ovariectomized on Day 3 and received $1 \mathrm{mg}$ progesterone/day on Days 3 to 9 . The mice were given 1.0 or $2.5 \mu \mathrm{g}$ of erythro-MEA or oil only at 11.00 hours on Days 5 and 6. Implantation of the delayed blastocysts was induced in half the animals by injection of $0.025 \mu \mathrm{g}$ of oestradiol at 12.00 hours on Day 6. All mice were killed on Day 10 and the uteri examined for implants or flushed for blastocysts.

In all experiments, the mice were placed at random into treatment groups and a double-blind technique used. Solutions of erythro-MEA in peanut oil were prepared from stock solutions in acetone. All injections were given by the subcutaneous route. The numbers of mice with implants were analysed by $\chi^{2}$ (corrected) in a $2 \times 2$ table. The numbers of ova recovered on Day 4 and the deciduomata scores and weights were subjected to analyses of variance. The levels of significance found from these statistical tests are given in the text.

\section{RESULTS}

Table 1 shows that treatment with erythro-MEA on Days 1 to 3 reduces the

TABLE 1

THE EFFEGTS OF ERYTHRO-MEA ON EARLY PREGNANCY IN THE MOUSE

\begin{tabular}{|c|c|c|c|c|c|c|}
\hline \multirow{2}{*}{$\begin{array}{l}\text { Treatment } \\
\text { on Days } 1 \text { to } 3 *\end{array}$} & \multirow{2}{*}{$\begin{array}{c}\text { Daily } \\
\text { dose }(\mu g)\end{array}$} & \multicolumn{3}{|c|}{ Mean ovum counts on Day $4 \dagger$} & \multirow{2}{*}{$\begin{array}{c}\% \text { with } \\
\text { implants } \\
\text { on Day } 12 \ddagger\end{array}$} & \multirow{2}{*}{$\begin{array}{l}\text { Mean } \\
\text { no. of } \\
\text { implant }\end{array}$} \\
\hline & & Oviduct & Uterus & Total & & \\
\hline Peanut oil & $0.1 \mathrm{ml}$ & $0 \cdot 8$ & $7 \cdot 8$ & $8 \cdot 5$ & 90 & $14 \cdot 7$ \\
\hline Erythro-MEA & $\begin{array}{l}0 \cdot 16 \\
0 \cdot 4 \\
1 \cdot 0 \\
2 \cdot 5\end{array}$ & $\begin{array}{l}0 \cdot 3 \\
2 \cdot 6 \\
2 \cdot 6 \\
3 \cdot 5\end{array}$ & $\begin{array}{r}11 \cdot 0 \\
8 \cdot 3 \\
1 \cdot 0 \\
1 \cdot 5\end{array}$ & $\begin{array}{r}11 \cdot 3 \\
10 \cdot 9 \\
3 \cdot 6 \\
5 \cdot 0\end{array}$ & $\begin{array}{l}80 \\
40 \\
10 \\
20\end{array}$ & $\begin{array}{l}9 \cdot 0 \\
7 \cdot 3 \\
3 \cdot 0 \\
5 \cdot 0\end{array}$ \\
\hline
\end{tabular}

* Mated mice received daily injections of peanut oil or erythro-MEA on Days 1, 2 and 3 of pregnancy and were killed on either Day 4 or Day 12.

+ Eight mice/group.

$\ddagger$ Ten mice/group. 
numbers of mice with implants on Day $12\left(\chi_{(1)}^{2}=6.9, P<0.01\right)$. The data for the distribution of ova in the tract on Day 4 show that the two highest doses of erythro-MEA reduced the recovery of ova to approximately $60 \%$ of that in control mice, and most of the ova recovered were in the oviduct. The lower doses of erythro-MEA did not significantly affect tubal transport. Analyses of variance of the numbers of eggs recovered show that the overall differences between the effects of erythro-MEA and oil were not significant, but that significant linear dose-response lines for the effects of erythro-MEA were established for oviducal ova $(P<0.05)$; uterine ova $(P<0.001)$; and for total recovery of ova $(P<0 \cdot 01)$, even though the slope for oviducal ova was opposite in sense to the overall slope.

The data in Table 2 show that erythro-MEA inhibited the deciduoma reaction in both intact and ovariectomized mice (for weights and scores, $P<0.001$ in both experiments). In pseudopregnant mice, the incidence of positive responses

TABLE 2

THE EFFECT OF ERYTHRO-MEA ON THE DECIDUOMA REAGTION IN PSEUDOPREGNANT AND OVARIEGTOMIZED MICE

\begin{tabular}{|c|c|c|c|c|}
\hline Treatment* & $\begin{array}{c}\text { Daily } \\
\text { dose }(\mu g)\end{array}$ & $\begin{array}{c}\% \text { with } \\
\text { deciduomata }\end{array}$ & $\begin{array}{c}\text { Mean } \\
\text { DIS }\end{array}$ & $\begin{array}{c}\text { Mean deciduoma } \\
\text { weight (mg) }\end{array}$ \\
\hline \multicolumn{5}{|l|}{$\begin{array}{l}\text { Pseudopregnant mice } \\
\text { (23 mice/group) }\end{array}$} \\
\hline Peanut oil & $0.1 \mathrm{ml}$ & $52 \cdot 1$ & 1.8 & $249 \cdot 0$ \\
\hline Erythro-MEA & $\begin{array}{l}0 \cdot 16 \\
0 \cdot 4 \\
1 \cdot 0 \\
2 \cdot 5\end{array}$ & $\begin{array}{r}47 \cdot 8 \\
30 \cdot 4 \\
13 \cdot 0 \\
8 \cdot 7\end{array}$ & $\begin{array}{l}1 \cdot 1 \\
0 \cdot 7 \\
0 \cdot 1 \\
0 \cdot 1\end{array}$ & $\begin{array}{l}69 \cdot 0 \\
53 \cdot 0 \\
14 \cdot 0 \\
47 \cdot 0\end{array}$ \\
\hline \multicolumn{5}{|l|}{$\begin{array}{l}\text { Ovariectomized mice } \\
\text { (12 mice/group) }\end{array}$} \\
\hline Peanut oil & $0.1 \mathrm{ml}$ & $100 \cdot 0$ & $3 \cdot 0$ & $247 \cdot 0$ \\
\hline Erythro-MEA & $\begin{array}{l}0 \cdot 16 \\
0 \cdot 4 \\
1 \cdot 0 \\
2 \cdot 5\end{array}$ & $\begin{array}{l}0 \\
0 \\
0 \\
0\end{array}$ & $\begin{array}{l}0 \\
0 \\
0 \\
0\end{array}$ & $\begin{array}{l}6.0 \\
6.0 \\
5.0 \\
4.0\end{array}$ \\
\hline
\end{tabular}

* Varying doses of erythro-MEA or the vehicles only were given on Days 1 to 3 of pseudopregnancy or Days 2 to 4 of progesterone treatment.

was rather low at $52 \cdot 1 \%$, while complete inhibition of decidualization did not occur even with the highest dose of erythro-MEA. By contrast, in ovariectomized mice, all doses of erythro-MEA completely inhibited decidualization.

In the pseudopregnant mice in Table 3, erythro-MEA significantly reduced the numbers of mice with implants following ovum transfers $\left(\chi_{(1)}^{2}=16 \cdot 1\right.$, $P<0.001)$. Treatment with oestradiol after transfer did not reverse this effect. In ovariectomized mice, ova will implant only if oestradiol is given at or after transfer (Humphrey, 1967a, 1968a, 1969). Treatment with erythro-MEA before transfer inhibits oestradiol-induced implantation $\left(\chi_{(1)}^{2}=22 \cdot 3, P<0 \cdot 001\right)$. Three of nine erythro-MEA-treated mice given oestradiol on Day 7 had implants on Day 12 , suggesting that the inhibitory influence of erythro-MEA had decreased by Day 7 . 
Implantation of delayed blastocysts in the mouse requires oestrogen (Humphrey, 1967c). By Day 10, only one mouse out of twenty not given oestradiol developed an implant (Table 4), although thirteen had free blastocysts. Spon-

TABLE 3

THE EFFECTS OF ERYTHRO-MEA ON IMPLANTATION IN OVUM TRANSFER EXPERIMENTS

\begin{tabular}{|c|c|c|c|c|}
\hline \multicolumn{2}{|c|}{ Treatment* } & \multirow{2}{*}{$\begin{array}{l}\text { No. with } \\
\text { implants }\end{array}$} & \multirow{2}{*}{$\begin{array}{l}\text { \% with } \\
\text { implants }\end{array}$} & \multirow{2}{*}{$\begin{array}{c}\text { Mean no. of } \\
\text { implants }\end{array}$} \\
\hline $\begin{array}{l}\text { Before } \\
\text { transfer }\end{array}$ & $\begin{array}{c}\text { Oestradiol } \\
\text { after transfer }\end{array}$ & & & \\
\hline \multicolumn{2}{|l|}{ Pseudopregnant } & & & \\
\hline Peanut oil & $\begin{array}{c}-\overline{ } \\
\text { Day } 5 \\
\text { Day } 6\end{array}$ & $\begin{array}{c}14 / 22 \\
3 / 6 \\
4 / 6\end{array}$ & $\begin{array}{l}63.7 \\
50 \cdot 0 \\
66.7\end{array}$ & $\begin{array}{l}2 \cdot 8 \\
2 \cdot 7 \\
3 \cdot 8\end{array}$ \\
\hline Erythro-MEA & $\begin{array}{c}- \\
\text { Day } 5 \\
\text { Day } 6\end{array}$ & $\begin{array}{l}2 / 19 \\
0 / 5 \\
1 / 6\end{array}$ & $\begin{array}{c}10 \cdot 5 \\
0 \\
16 \cdot 7\end{array}$ & $\begin{array}{l}0.2 \\
0.0 \\
0.3\end{array}$ \\
\hline \multicolumn{2}{|l|}{ Ovariectomized } & & & \\
\hline Peanut oil & $\begin{array}{l}\text { Day } 5 \\
\text { Day } 6 \\
\text { Day } 7\end{array}$ & $\begin{array}{c}10 / 12 \\
6 / 9 \\
9 / 9\end{array}$ & $\begin{array}{r}83 \cdot 3 \\
66 \cdot 7 \\
100 \cdot 0\end{array}$ & $\begin{array}{l}3 \cdot 0 \\
2 \cdot 6 \\
5 \cdot 3\end{array}$ \\
\hline Erythro-MEA & $\begin{array}{l}\text { Day } 5 \\
\text { Day } 6 \\
\text { Day } 7\end{array}$ & $\begin{array}{l}1 / 10 \\
1 / 9 \\
3 / 9\end{array}$ & $\begin{array}{l}10 \cdot 0 \\
11 \cdot 1 \\
33.3\end{array}$ & $\begin{array}{l}0 \cdot 1 \\
0 \cdot 1 \\
1 \cdot 0\end{array}$ \\
\hline
\end{tabular}

* Pseudopregnant and progesterone-treated ovariectomized mice received $0.1 \mathrm{ml}$ peanut oil daily or $1.0 \mu \mathrm{g}$ erythro-MEA daily on Days 1 to 3 of pseudopregnancy or Days 2 to 4 of progesterone treatment, respectively. Eight ova were transferred on Day 4, and in some mice implantation was induced by $0.025 \mu \mathrm{g}$ of oestradiol as shown below.

TABLE 4

THE EFFECTS OF ERYTHRO-MEA ON DELAYED IMPLANTATION IN THE MOUSE

\begin{tabular}{l|c|c|c|c|c|c|c}
\hline $\begin{array}{c}\text { Treatment* } \\
\text { on Days } 5 \text { and } 6\end{array}$ & $\begin{array}{c}\text { Treatment } \\
\text { on } \\
\text { Day } 6\end{array}$ & $\begin{array}{c}\text { No. with } \\
\text { implants }\end{array}$ & $\begin{array}{c}\% \text { with } \\
\text { implants }\end{array}$ & $\begin{array}{c}\text { Mean } \\
\text { no. of } \\
\text { implants }\end{array}$ & $\begin{array}{c}\text { No. with } \\
\text { free } \\
\text { blastocysts }\end{array}$ & $\begin{array}{c}\text { \% with } \\
\text { free } \\
\text { blastocysts }\end{array}$ & $\begin{array}{c}\text { Mean no. } \\
\text { with free } \\
\text { blastocysts }\end{array}$ \\
\hline Peanut oil & Oil & $1 / 20$ & 5 & 0.6 & $13 / 20$ & 85 & $2 \cdot 3$ \\
Peanut oil & Oestradiol & $16 / 18$ & 89 & $8 \cdot 1$ & $0 / 18$ & 0 & 0.0 \\
Erythro-MEA 1.0 $\mu \mathrm{g} /$ day & - & $9 / 18$ & 50 & 3.2 & $5 / 18$ & 28 & 0.6 \\
Erythro-MEA 1.0 $\mu \mathrm{g} /$ day & Oestradiol & $8 / 18$ & 44 & 2.2 & $6 / 18$ & 33 & 1.2 \\
Erythro-MEA 2.5 $\mu \mathrm{g} /$ day & - & $7 / 16$ & 42 & 1.3 & $1 / 16$ & 7 & 0.3 \\
Erythro-MEA 2.5 $\mu \mathrm{g} /$ day & Oestradiol & $7 / 18$ & 39 & 1.9 & $3 / 18$ & 17 & 0.2 \\
\hline
\end{tabular}

* Ovariectomized, progesterone-treated, pregnant mice received erythro-MEA or oil on Days 5 and 6 at 11.00 hours, and $0.025 \mu \mathrm{g}$ of oestradiol or oil at 12.00 hours on Day 6 and were killed on Day 10 .

taneous implants are believed to be due to endogenous oestrogen released before ovariectomy (Humphrey, 1967c). Oestradiol on Day 6 induced implantation in sixteen of eighteen vehicle-treated mice and free blastocysts were not present in the remaining two animals. 
Treatment with either 1.0 or $2.5 \mu \mathrm{g}$ of erythro-MEA on Days 5 and 6 induced implantation in $50 \%$ and $42 \%$ of the mice, respectively (erythro-MEA versus control, $\left.\chi_{(1)}^{2}=8.5, P<0.01\right)$ and free blastocysts were present in $28 \%$ and $7 \%$ of the animals, respectively. Thus, erythro-MEA, although not as effective as oestradiol, induces implantation in a proportion of mice, and behaves as an oestrogen.

When oestradiol was given on Day 6, the number of mice with implants in the group pre-treated with erythro-MEA was significantly less than in the group pre-treated with oil $\left[\chi_{(1)}^{2}=9 \cdot 1, P<0 \cdot 01\right]$. It seems that erythro-MEA can prevent oestradiol-induced implantation and so also behaves as an antioestrogen.

\section{DISCUSSION}

In the experiment on tubal transport, erythro-MEA caused tube-locking of some ova on Day 4, and reduced the recovery of ova to about $60 \%$ of that in control mice. These effects are very similar to those produced by multiple injections of U-10997 or oestradiol (Humphrey, 1967b; Humphrey \& Martin, $1968 \mathrm{a}, \mathrm{b})$. The loss of ova, in oestradiol-treated mice at least, is due to accelerated transport from the oviduct to the uterus and vagina (Humphrey, 1968a). By contrast, the anti-oestrogens, U-11555A, U-11100A, MER-25 and MRL-37 cause tube-locking of all ova and do not reduce the recovery of ova (Humphrey, 1967b; Humphrey \& Martin, 1968a, b).

In addition, erythro-MEA has oestrogen-like effects on decidualization, since it inhibits the deciduoma reaction and the implantation of transferred ova in pseudopregnant and ovariectomized mice (see Courrier, 1950; Davis, 1963; Stone \& Emmens, 1964; Humphrey, 1968c). But, although the deciduoma reaction is very sensitive to the level of oestrogen (Courrier, 1950), implantation in ovariectomized mice is not (Humphrey, 1969). The inhibition of oestradiolinduced implantation of transferred ova in ovariectomized mice appears to be an anti-oestrogenic action.

In ovariectomized, pregnant mice with delayed blastocysts, erythro-MEA induces implantation in a percentage of mice and also inhibits oestradiolinduced implantation in the remaining animals. Thus, erythro-MEA exhibits both oestrogenic and anti-oestrogenic actions at the dose levels used in this experiment and behaves in a similar fashion to oestriol, an impeded oestrogen (Humphrey, 1967c). This is an unexpected result since erythro-MEA at such low doses shows little activity in routine oestrogen assays of the rodent vagina (Emmens, 1967). But in promoting the uptake of tritiated uridine by the mouse uterus, erythro-MEA is as effective as hexoestrol, has one-third of the potency of oestradiol, and is a very potent oestrogen in that particular context (B. G. Miller, personal communication). This effect demonstrates that, in blocking the feminizing effects of oestradiol, erythro-MEA acts as an oestrogen. This action is not sustained unless higher multiple doses are given. Presumably erythro-MEA, like DMS (Martin, Emmens \& Cox, 1960) does not remain at the site of action for more than a short period (about $15 \mathrm{~min}$ ).

It seems that erythro-MEA can stimulate some of the endometrial changes characteristic of oestrogen, and can induce implantation in a proportion of 
mice. However, this stimulation is incomplete, and erythro-MEA also acts as an anti-oestrogen. It can reasonably be assumed that the anti-fertility actions of erythro-MEA at the dose levels used here are due to its anti-oestrogenic properties.

\section{ACKNOWLEDGMENTS}

\section{This work was supported by a grant from the Ford Foundation (U.S.A.).}

\section{REFERENCES}

Courrier, R. (1950) Interactions between estrogens and progesterone. Vitams Horm. 8, 179.

DAvis, B. K. (1963) Studies on the termination of pregnancy with norethynodrel. 7. Endocr. 27, 99.

Duncan, G. W. \& Forbes, A. D. (1965) Blastocyst survival and nidation in rats treated with oestrogen antagonists. F. Reprod. Fert. 10, 161.

Emmens, G. W. (1965) Oestrogenic, anti-oestrogenic and antifertility activities of various compounds. 7. Reprod. Fert. 9, 277.

Emmens, C. W. (1967) Recent progress in fertility control in animals and man. Proc. IIIrd Asia Oceania Congr. Endocr., Manila, p. 43. Ed. A. D. Litonjua.

Emmens, C. W. \& MARTin, L. (1965) Biological activities of U-11100A. J. Reprod. Fert. 9, 269.

Humphrey, K. W. (1967a) The development of viable embryos after ovum transfers to long term ovariectomised mice. Steroids, 9, 53.

Humphrey, K. W. (1967b) Anti-fertility actions of some anti-oestrogens in the mouse. Proc. IIIrd Asia Oceania Congr. Endocr., Manila, Pt II, p. 784. Ed. A. D. Litonjua.

Humphrey, K. W. (1967c) The induction of implantation in the mouse after ovariectomy. Steroids, 10, 591.

Humphrey, K. W. (1968a) The hormonal control of implantation in some laboratory animals. Paper presented to Section I, Human and Animal Fertility, ANZAAS Congress, Christchurch, N.Z.

Humphrey, K. W. (1968b) The effects of some anti-oestrogens on the deciduoma reaction and delayed implantation in the mouse. 7. Reprod. Fert. 16, 201.

HUMPhREY, K. W. (1968c) The effects of oestradiol $3: 17 \beta$ on tubal transport in the laboratory mouse. 7. Endocr. 42, 17.

HuMpHrEY, K. W. (1969) The induction of implantation of blastocysts transferred to ovariectomized mice. F. Endocr. 44, 299.

Humphrey, K. W. \& Martin, L. (1968a) The effects of oestrogens and anti-oestrogens on early pregnancy in mice. F. Reprod. Fert. 15, 191.

Humphrey, K. W. \& MARTin, L. (1968b) The effects of oestrogen and anti-oestrogens on ovum transport in the laboratory mouse. Aust. F. biol. Sci. 21, 1239.

Martin, L., Emmens, G. W. \& Cox, R. I. (1960) The effects of oestrogens and anti-oestrogens on early pregnancy in mice. F. Endocr. 20, 299.

Pincus, G., Chang, M. C., Zarrow, M. X., Hafez, E. S. E. \& Merrill, A. P. (1956) Studies on the biological activity of certain 19-non-steroids in female animals. Endocrinology, 59, 695.

SCHLOUGH, J. S. \& MEYER, R. K. (1965) Effect of anti-estrogens on estrogen-induced ova implantation in the ovariectomized rat. Fert. Steril. 16, 106.

Stone, G. M. \& Emmens, G. W. (1964) The action of oestradiol and dimethylstilboestrol on early pregnancy and deciduoma formation in the mouse. F. Endocr. 29, 137. 